TECHNICAL TRANSACTIONS 4/2017

CZASOPISMO TECHNICZNE 4/2017

MECHANICS

DOI: $10.4467 / 2353737$ XCT.17.060.6371

\title{
Damian Semba
}

Anna Trusek-Hołownia (anna.trusek-holownia@pwr.edu.pl)

Department of Bioprocess and Biomedical Engineering, Faculty of Chemistry, Wroclaw

University of Science and Technology

\section{GENERATION OF HOMO- AND HETEROGENEOUS MICROCAPSULES}

AND THEIR APPLICATION

\section{WYTWARZANIE HOMO- I HETEROGENICZNYCH MIKROKAPSUŁEK}

ORAZ ICH ZASTOSOWANIE

\begin{abstract}
Microencapsulation is defined as a process during which the whole envelopment with (bio)catalysts, substrates etc. is included into hydrogel and/or surrounded by a porous polymeric membrane. However, the production of homogeneous, narrow size, distributed capsules is quite troublesome. The main problem is the way of obtaining a large number of capsules with a precisely predefined size. It is possible due to a device called an encapsulator. This equipment allows to produce homogeneous beads and core-shell systems with a predefined size in the range from $400 \mu \mathrm{m}$ to $1600 \mu \mathrm{m}$, which is possible because of special nozzles with different diameters. There are a lot of microcapsule applications. In this paper, we would like to present the construction, principles of operation and selected applications of microencapsulation devices using the example of the BÜCHI-B390 encapsulator.
\end{abstract}

Keywords: microencapsulation; homogeneous beads; core-shell systems; encapsulator BÜCHI-B390

\section{Streszczenie}

Mikrokapsułkowanie definiowane jest jako proces, w którym całe środowisko zawierające m.in. (bio)katalizatory, substraty itp. zamykane jest w sieci hydrożelu i/lub otaczane porowatą polimerową membraną. Wytwarzanie jednorodnych kapsułek o wąskim rozkładzie wielkości jest dość kłopotliwe. Głównym problemem do rozwiązania jest sposób uzyskania dużej liczby kapsułek o dokładnie zdefiniowanej wielkości. Jest to możliwe przy użyciu urządzenia zwanego enkapsulatorem. Pozwala ono na wytwarzanie homogenicznych kapsułek i układów rdzeń-powłoka o zdefiniowanej wielkości w zakresie od 400 um do 1600 $\mu \mathrm{m}$, co jest możliwe za pomocą zestawu dysz o różnych średnicach. Istnieje wiele aplikacji mikrokapsułek. W artykule przedstawiona zostanie budowa, zasada działania i wybrane zastosowania urządzenia do mikroenkapsulacji na przykładzie enkapsulatora BUCHI-B390.

Słowa kluczowe: mikroenkapsulacja; homogeniczne mikrokapsułki; układy rdzeń-powłoka; enkapsulator BÜCHI-B390 


\section{Microencapsulation}

Microencapsulation is often defined as a process in which some substances are entrapped in a coating, made of polymers, in order to obtain small capsules. These capsules have many useful properties. Mostly, this technique plays a large role in the food industry incorporation of food ingredients, enzymes; however, nowadays, it is possible to distinguish more applications - in the pharmaceutical industry, it is used to enclose solids, liquids, or gases inside very thin wall, made of hard or soft soluble layer, in order to reduce the dosing frequency and prevent the degradation of active substance [1].

Microencapsulation techniques have to meet specific criteria in order to be introduced into the industry. These criteria could be subdivided into 2 groups [2]. The first one focuses on such issues like technical aspects of producing capsules, for example, simplicity of the method, high efficiency, ability to use viscous solutions, obtaining a range of different sized capsules and short time of production. The second group concerns capsule characteristics and narrow size distribution.

Microcapsules have been produced with various techniques, which differ from each other. Table 1 contains some examples. A lot of them is the modification of three basic techniques: phase separation (coacervation), solvent extraction/evaporation and spray-drying [3].

Table 1. Examples of microencapsulation methods [7]

\begin{tabular}{|c|l|}
\hline \multicolumn{1}{|c|}{ Chemical processes } & \multicolumn{1}{c|}{ Mechanical processes } \\
\hline Solvent evaporation and extraction & Spray drying \\
\hline Cryogenic solvent extraction & Spray chilling \\
\hline Phase separation (coacervation) & Spray desolvation \\
\hline Non-solvent addition & Supercritical fluid precipitation \\
\hline Temperature change & Spinning disk and centrifugal coextrusion \\
\hline Incompatible polymer or salt addition & Extrusion \\
\hline Polymer-polymer or salt addition & Jet excitation \\
\hline Polyelectrolyte complexation & \\
\hline Interfacial polymerization & \\
\hline
\end{tabular}

Coacervation is a fast and simple method, but there are some solvent residues, which have to be ridden off, and often coacervating agents are present in microcapsules [4]. Another relatively easy method is spray-drying, but it cannot be used for thermolabile compounds. Moreover, control of the particle size during this method is difficult and yields are not so high [5]. 
The method used by an encapsulator device is called jet vibration (excitation). Studied by Rayleigh in late $19^{\text {th }}$ century [6], it is based on the principle that using vibration frequency with a selected amplitude for a laminar jet will break it, which results in the formation of a droplet chain (equal size). It has been reported that this technique allows to obtain monodispersed homogeneous, spherical beads, with a narrow-size distribution. Simplicity of operation and setup are very important advantages. The production of droplets is not time-consuming and the efficiency is very high. Additionally, the jet-break up technique allows to operate under sterile conditions, which are compulsory for cell or microorganism encapsulation [8]. However, producing small sized particles $(<100 \mathrm{pm})$ is quite troublesome and it demands the application of a different method.

In the mentioned technique, an operator obtains a single droplet chain, which means that one droplet is produced at a given time and the flow rate is closely related to the nozzle diameter [9]. Even if the nozzle diameter was larger, the production volume will still be at the same level. Scaling of the process is carried out by increasing the number of nozzles. The inability to extrude high viscosity polymers is another disadvantage of jet break-up systems. The high viscosity effect is minimized by increasing the temperature of the vibrating chamber during extrusion, but it works only to a certain extent. Because of that, low concentration solutions of polymers are applied, resulting in limited mechanical resistance of microcapsules [9]. Heating systems were developed by EnCapBioSystems and are currently supplied by BÜCHI [10].

\section{Vibration jet system}

The theoretical basis of a vibrational system are the Newtonian fluid dynamics, although there are reports indicating that it could be also applied for non-Newtonian liquids, such as carrageenans or alginates, in order to obtain microspheres by ionotropic gelation [11]. Some equations were applied to approximate the frequency and flow rates in order to obtain a break up of the laminar jet of a polymer into a droplet chain [12]. Serp et al., implied that, in order to determine values for the nozzle diameter using the empirical approach, all calculated values should be treated like a reference point [11]. Another important factor is that the size of the obtained capsule does not equal the diameter of the applied nozzle [13]. During formation of the droplet chain, there is also a necessity to disperse newly created spheres in order to prevent agglomeration (without dispersion, coalescence between droplets will lead to beads of double or triple volume). In the above system, this effect is accomplished by electrostatic repulsion forces system. It was first introduced by Brandenberger et al. [14]. Electrostatic field right after break-up charges the droplets and because of this fact - agglomeration effect is eliminated. Thanks to dispersion, microcapsules are distributed over a large surface of hardening bath, which results in monodispersed beads [12]. According to Brandenberger et al., the electrode potential is supposed to be in the range of $400-2500 \mathrm{~V}$, which is strictly connected with the droplet diameter and jet velocity [14]. 


\subsection{Encapsulator BÜCHI B-390}

The device consists of several main parts. These are: bead producing unit, pressure bottles, and control unit (Fig. 1). The possibility of sterilizing (by autoclaving) all parts, which have contact with polymeric mixture, is another great advantage.

The agent intended for encapsulation (enzymes, cells, chemicals) is mixed with a polymer. The mixture is placed in a pressure bottle (1) and forced into the bead-producing unit (2) by adjustable air pressure $(\mathbf{P})$. When the liquid is passing through the nozzle, thanks to vibrating unit (3), the laminar jet is broken up into equally sized droplets. The obtained droplets are then directed towards the electrical field between the nozzle (4) and the electrode (5) resulting in a surface charge. Because of that, beads are dispersing and they will not agglomerate before they fall down to the hardening bath (9). Additionally, the bath is electrically grounded to avoid the negative effect of "jumping" beads out of the beaker. During the process, it is possible to set the temperature of the apparatus - it can help with high viscosity liquids. The only difference between a single nozzle system and a concentric nozzle system is in the mounted pulsation chamber and the type of nozzle (both setups are presented in materials and method chapter).

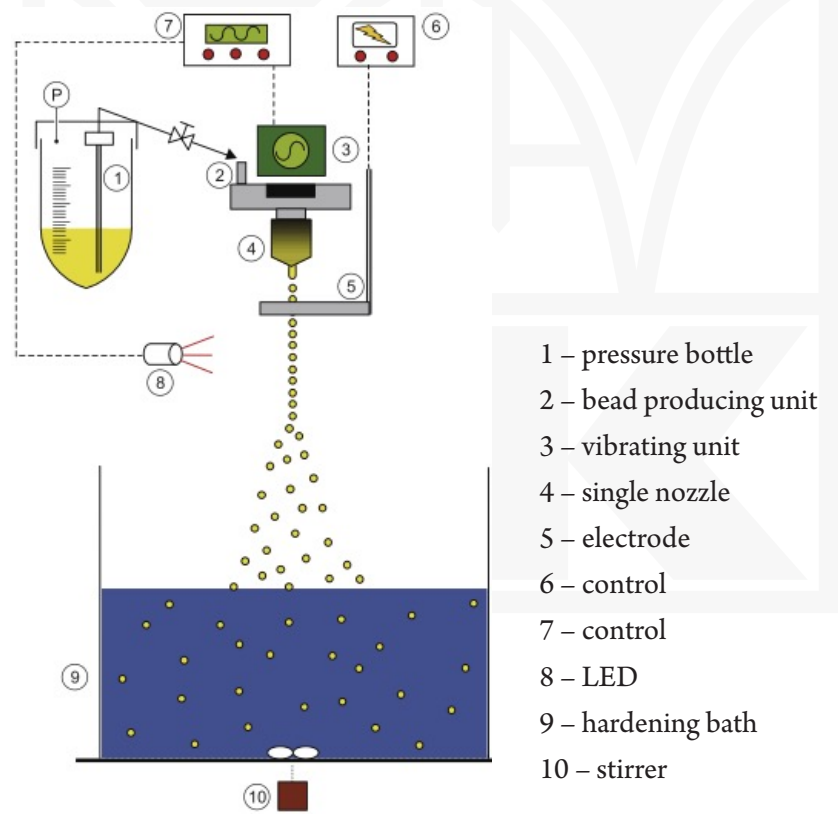

Fig. 1. Schematic representation of the Encapsulator B-390

\subsection{Nozzle configuration}

The Encapsulator B-390 has four different nozzle configurations. The selected system depends on the type of beads/capsules, their assumed sizes and the material, which will be encapsulated. The first type is a single nozzle system, which allows to produce beads with 
a predefined size from $150 \mu \mathrm{m}$ to $4 \mathrm{~mm}$. The second type is a concentric nozzle system, which enables to obtain core-shell capsules in single step process. The encapsulator may also be equipped with a flow vibration nozzle. It is used to produce smaller beads (size around $80 \mu \mathrm{m})$ from viscous solutions. Another configuration provided by the manufacturer is an air dripping nozzle system, which allows for encapsulation islets and cell clusters in beads. The evaluated configurations consist of the first two presented systems (Fig. 2) - single and concentric nozzle, the capabilities of which have been tested.
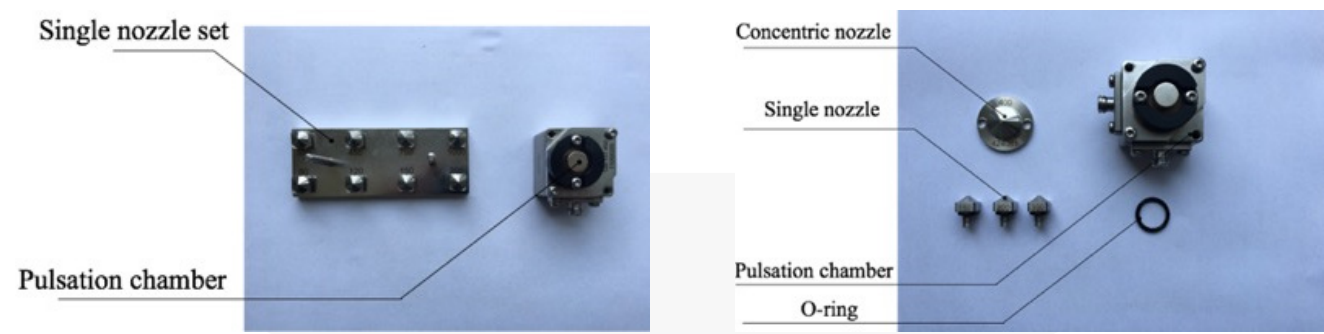

Fig. 2. Single nozzle configuration (left) and concentric nozzle setup (right)

\subsection{Large scale production}

The encapsulator provided by BUCHI is designed for research and development work and for producing small amounts of beads and capsules for commercial purposes. Mostly, it is used for the encapsulation of small quantities of specialized drugs and animal cells. After the development of encapsulation conditions, it could be used for larger scale production. Increasing the diameter of nozzle allows to obtain high production rates. According to the company, it is possible to establish the production rate at $40 \mathrm{ml} / \mathrm{min}$ [10]. Industrial production is much bigger - reaching several tonnes per day. In this case, it is achieved by increasing the number of nozzles. An encapsulator with a significant number of nozzles is able to extrude a polymer solution faster. Using values similar to the values developed in lab-scale, it enables the production of beads or capsules with much higher efficiency.

\section{Biopolymers used in microencapsulation}

There are a lot of biopolymers that are suitable for application in microencapsulation, particularly to obtain homogeneous structures. One of them is sodium alginate - linear anionic polysaccharide, distributed widely in the cell walls of brown algae, such as in Laminiaria digitata and L. Hyperboria [15]. Its structure can be divided into twoblocks: G-block ( $\alpha$-1,4-L-glucuronic acid) and M-block ( $\beta$-1,4-D-mannuronic acid). Its popularity is a result of the ability to create gels by exchanging sodium ions by divalent calcium ions. The most popular model, which explains the chain-to-chain association, is the "egg-box model" [16]. The obtained gels are relatively stable at an acidic $\mathrm{pH}$, but at an alkaline $\mathrm{pH}$, they could 
swell. Gels are biocompatible and easy to obtain. Therefore, alginate gel is widely used in drug delivery systems $[17,18,19]$ and cell tissue engineering [20]. It plays a great role in the microencapsulation of vitamins [21], fragrances and flavors [22 and 23]. Fig. 3 presents the capsules obtained by us based on sodium alginate.

a)

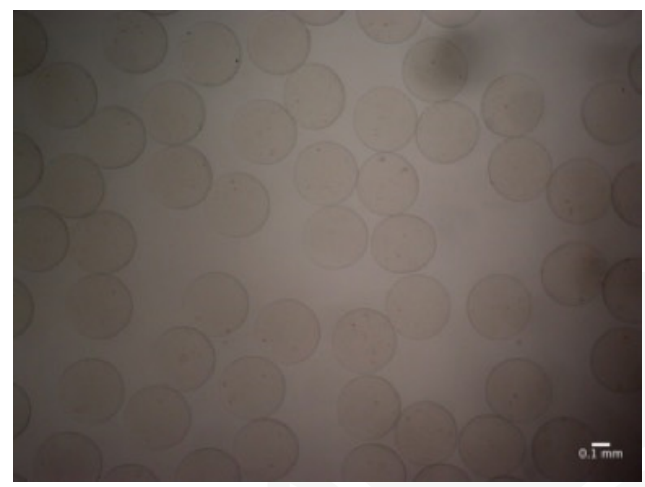

b)

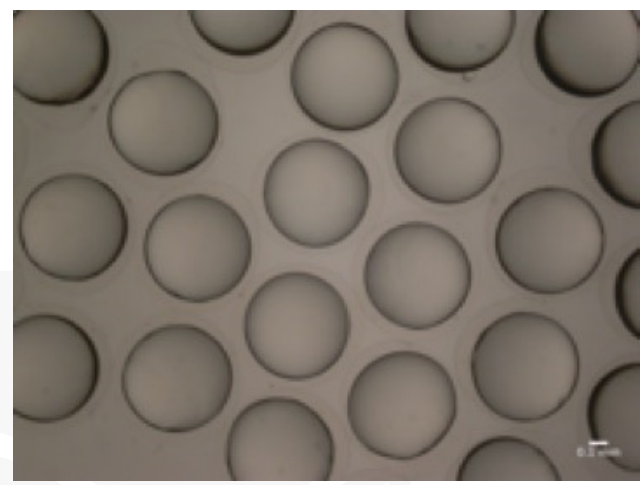

Fig. 3. Microscopic photographs of selected obtained microcapsules using the Encapsulator B-390 (Buchi): a) homogeneous from sodium alginate, nozzle size $150 \mathrm{~mm}$, frequency $900 \mathrm{~Hz}$, voltage 600 $\mathrm{V}$, pressure $394 \mathrm{mbar} ; 50^{\circ} \mathrm{C}$; b) heterogeneous with linseed oil in core and shelled by sodium alginate, concentric nozzle size $300 \mathrm{~mm}$, core nozzle size $150 \mathrm{~mm}$, frequency $790 \mathrm{~Hz}$, voltage $2500 \mathrm{~V}$, pressure $456 \mathrm{mbar} ; 50^{\circ} \mathrm{C}$

Another great biopolymer, very useful in microencapsulation, is $\mathrm{K}$-carrageenan. It is a member of a large linear group of sulphated polysaccharides that are obtained from red algae (major sources are Chondrus, Eucheuma, Gigartina) [24]. All carrageenans have a common backbone of alternating $\beta-1,3-\mathrm{D}$-galactose and $\alpha-1,4-\mathrm{D}$-galactose. For microencapsulating purposes, $\kappa$-carrageenan is used (Fig. 4). The differences that have a great influence on the properties of the above group include the number and position of the ester sulphate groups on repeating galactose units [25]. The higher the ester sulphate group content, the lower the solubility temperature of carrageenan. That phenomena occur in the production of lower strength gels or even inhibit gel formation ( $\lambda$-carrageenan). Gel is formed in the presence of potassium or sodium ions [26]. $\kappa$-carrageenan is used for encapsulating essential oils [27], probiotics [28] and microorganisms [29].

Another great polymer of natural origin is chitosan. It is a cationic linear polysaccharide composed of a deacetylated unit ( $\beta$-(1-4)-linked glucosamine) and a acetylated unit

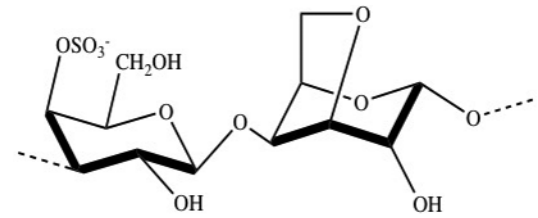

Fig. 4. $\kappa$-carrageenan (N-acetyl-D-glucosamine) in a random order. Chitosan does not occur in nature too often because of that, it is obtained by deacetylation of chitin (component of the cell walls of fungi and the exoskeletons of arthropods) [30]. The mentioned polysaccharide is nontoxic, biodegradable and biocompatible; all these features make it useful 
in medicine and pharmacy [31]. What is more, hipocholesterolemic, hipolipidemic [32], antimicrobial [33] and antitumor activity [34] of chitosan have been reported. It is very often used for encapsulating enzymes [35], in dentistry [36], but also to manufacture matrices for drug delivery [37].

\section{Applications of microencapsulation}

Simplicity, result reproducibility and high efficiency are the greatest advantages of microencapsulation by the vibration jet technique. Because of that, a lot of applications have been developed.

Immobilization of cell systems is one of the most widespread uses of microencapsulation. In the brewing industry, that aspect was investigated for the last 20 years. Microencapsulated systems were successfully used for the secondary fermentation of beer [38] and for the production of alcohol-free or low-alcohol beer [39]. Despite the success in the introduction of immobilized microorganisms to some stages of beer production, such systems have not been applied for primary beer fermentation. This is caused by flavor variation produced by immobilized cells in final beers [40]. The blame for this lies in the insufficient consumption of free amino nitrogen, mass transport difficulties and restricted cell growth [41]. The metabolism of amino acids in yeast is closely related to the synthesis of the flavor compound, such as higher alcohols, esters, sulphur compound or vicinal diketones. Increasing the amino acid consumption could be carried out by minimizing external and internal mass transfer resistances. To deal with that size, texture and porosity of the immobilized polymer, the particles have to be adjusted. A smaller diameter of particles significantly decreases internal mass transfer restrictions [42]. In order to entrap yeast cells, low-density alginate and carrageenan gel microcapsules were used [43]. The optimal diameter was estimated by a short cultivation study and it is $0.5-0.6 \mathrm{~mm}$ for alginate microbeads loaded with brewing yeast. That size induces rapid cell proliferation and minimizes restriction in the mass transfer [43].

Capsules consisting of hydrophobic core and cross-linked polymeric shells are another example of microencapsulation applications. The core-shell system could be used in capsular perstraction of inhibitory products from bioprocesses [44]. Such systems are promoting rapid mass transfer thanks to a high surface area. Preventing the formation of stabilized emulsions and problems with toxic effect of organic phases for microorganisms are omitted by the separation of organic phase (core) by the capsule membrane from an aqueous environment [45]. The predominance of the core-shell system over beads is a much larger surface area. The mentioned system was applied to 2-phenylethanol extraction from a yeast bioconversion process. It helps to overcome respiratory inhibition by both phenylethanol and dibutyl sebacate. As an organic phase core, dibutyl sebacate was used and it was entrapped in calcium alginate hydrogel to form autoclavable liquid-core capsules [45].

Microencapsulation is also a method used in order to protect bacteria against gastric conditions. The increased interest in the role of probiotics bacteria in human health led to the entrapment of lactic acid bacteria in food, resulting in a new generation of "improved" food. 
International Dairy Federation suggests that bacteria consumed within food should be active, abundant and to be at least $107 \mathrm{CFU} / \mathrm{g}$ [46]. The microencapsulation technique was used to investigate the survival of Lactobacillus acidophilus CSCC 2400 in simulated gastric conditions. The mentioned strain was encapsulated in calcium alginate with different concentrations and different sizes. As a result, it occurred that viability of the cells increased with an increase in the alginate capsule size and gel concentration. Research proved that the vibrating jet technique could be effectively used to produce microcapsules within an entrapped microorganism in order to protect it against harsh conditions in the human digestive system [47].

Enzyme encapsulation is also an example of the application of the vibrating jet technique in the dairy industry. During the cheese production process, in order to develop the flavor, texture and aroma, a long ripening time is required. Maturation of cheese in the traditional way demands a series of complex biochemical and microbiological processes and it takes a lot of time [48]. The simplest and easiest way to accelerate the process is to add exogenous enzymes, but because of enzyme loss in whey and a poor biocatalyst distribution, such a solution is uneconomical. However, encapsulated enzymes eliminate the enzyme irrecoverable problem and prevent immediate and extensive proteolysis as well as contamination of whey. At the end of the process, it is possible to separate immobilized enzyme from substrate in the milk and the curd mixture [49]. In Anjani et al. study, flavourzyme was encapsulated in alginate, chitosan and $\kappa$-carrageenan polymers. After encapsulation, the stability of the enzyme was investigated. Immobilization of flavourzyme in alginate matrix alone exhibited a poor immobilization efficiency, which was elevated by the addition of chitosan to the polymeric solution. Controlling the amount of released enzyme could modify the proteolysis, which is the main requirement for an optimal flavor development in cheese ripening [50].

Microencapsulation is also applied for improving the storage stability of various oils [51 and 52]. Oils and fats are products that are vulnerable to oxidation. Especially those, which are characterized by a high content of sensitive to oxidative deterioration components. This self-catalyzing process involves reactions like primary oxidation, secondary oxidation and hydrolytic rancidity [53]. Nowadays, instead of using some chemical additives to prevent oils form oxidizing, encapsulation techniques are applied. This provides a physical barrier (mostly made of biopolymers), which minimizes the influence of the external environment [54]. SunWaterhouse et al, proved that encapsulation of avocado oil significantly improves oil resistance to oxidation. During research, alginate and alginate-HMPC (hydroxypropyl methylcellulose) systems were compared. The combination of alginate and HPMC was a worse encapsulant than alginate alone [52].

\section{Conclusions}

For some time, microencapsulating techniques played a big role and found application in many industries, such as food, medical, biotechnology, agriculture, cosmetics. There are a lot of rules, which are obligatory to follow, if microcapsules are supposed to be introduced 
to the market. Medical applications demand monodisperse, homogeneous, and spherical beads/capsules, with a small size and a narrow size distribution. To meet the mentioned requirements, jet-break up techniques are used. These techniques are quite easy to operate and have other useful features like high efficiency and short production time. A device called the encapsulator allows to produce beads/capsules, which meet most of the criteria. With the help of this device, even heterogeneous core-shell system, with predefined sizes of core and capsule, could be obtained. Moreover, it enables large-scale production due to the increased nozzle number.

Encapsulator BÜCHI B-390 is a device, which allows to obtain homogeneous beads of variable sizes with great efficiency and reproducibility. The device also enables to obtain heterogeneous capsules with predefined sizes of both the capsule as well as the core. The influence of some parameters on beads size was noticed. Increasing the nozzle size required a lower vibration frequency and an increased flow rate. Increasing the nozzle size and flow rate have a major influence on productivity.

This work was performed within the Project No. 2013/11/B/ST8/03672 sponsored by the National Science Centre (NCN) of Poland.

\section{References}

[1] López A.F., Deladino L., Alba S.N., Miriam N.M., Encapsulación de compuestos bioactivos con alginatos para la industria de alimentos, limentech, Ciencia y Tecnología Alimentaria, 10(1), 2011.

[2] Whelehan M., Marison I.W., Microencapsulation using vibrating technology, Journal of microencapsulation, 28(8), 2011, 669-688.

[3] Aftabrouchad C., Doelker E.S.T.P., Méthodes de préparation des microparticules biodégradables chargées en principes actifs hydrosolubles, STP pharma sciences, 2(5), 1992, 365-380.

[4] Thomasin C., Johansen P., Alder R., Bemsel R., Hottinger G., Altorfer H., Wright A.D., A Contribution to Overcoming the Problem of Residual Solvents in Biodegradable Microspheres, Prepared by. Eur. J. Pharm. Biopharm, 42, 1996, 1.

[5] Johansen P., Merkle H. P., Gander B. Technological considerations related to the up-scaling of protein microencapsulation by spray-drying, European Journal of Pharmaceutics and Biopharmaceutics, 50(3), 2000, 413-417.

[6] Rayleigh L., Philosophical Magazine, Series 5, 1882, 184-186.

[7] Yeo Y., Baek N., \& Park K., Microencapsulation methods for delivery of protein drugs, Biotechnology and Bioprocess Engineering, 6(4), 2001, 213-230.

[8] Vemmer M., Patel A.V., Review of encapsulation methods suitable for microbial biological control agents, Biological Control, 67(3), 2013, 380-389.

[9] Whelehan M., Marison I.W., Microencapsulation using vibrating technology, Journal of microencapsulation, 28(8), 2011, 669-688. 
[10] BUCHI Labortechnik AG. Encapsulators B-390/B-395 Pro, Technical data sheet, http:// www.buchi.com/en/content/spray-drying-encapsulation-solutions (access: July 2016).

[11] Serp D., Cantana E., Heinzen C., Von Stockar U., Marison I.W., Characterization of an encapsulation device for the production of monodisperse alginate beads for cell immobilization, Biotechnology and bioengineering, 70(1), 2000, 41-53.

[12] Heinzen C., Berger A., Marison I., Use of vibration technology for jet break-up for encapsulation of cells and liquids in monodisperse microcapsules, In Fundamentals of cell immobilisation biotechnology Springer Netherland 2004, 257-275.

[13] Marison I., Peters A., Heinzen C., Liquid Core Caspules for Applications in Biotechnology. In Fundamentals of cell immobilisation biotechnology 2004, Springer Netherlands 2004, 185-204.

[14] Brandenberger H., Nüssli D., Piech V., Widmer F., Monodisperse particle production: A method to prevent drop coalescence using electrostatic forces, Journal of electrostatics, 45(3), 1999, 227-238.

[15] Kikuchi A., Kawabuchi M., Sugihara M., Sakurai Y., Okano T., Pulsed dextran release from calcium-alginate gel beads, Journal of Controlled Release, 47(1), 1997, 21-29.

[16] Morris E.R., Rees D.A., Thom D., Boyd J., Chiroptical and stoichiometric evidence of a specific, primary dimerisation process in alginate gelation, Carbohydrate research, 66(1), $1978,145-154$.

[17] Lee B.J., Min G.H., Oral controlled release of melatonin using polymer-reinforced and coated alginate beads, International journal of pharmaceutics, 144(1), 1996, 37-46.

[18] Kamath K.R., Park K., Biodegradable hydrogels in drug delivery, Advanced Drug Delivery Reviews, 11(1), 1993, 59-84.

[19] González-Rodriguez M.L., Holgado M.A., Sanchez-Lafuente C., Rabasco A.M., Fini A., Alginate/chitosan particulate systems for sodium diclofenac release. International Journal of Pharmaceutics, 232(1), 2002, 225-234.

[20] Wang L., Shelton R.M., Cooper P.R., Lawson M., Triffitt J.T., Barralet J.E., Evaluation of sodium alginate for bone marrow cell tissue engineering, Biomaterials, 24(20), 2003, 3475-3481.

[21] Yoo S.H., Song Y.B., Chang P.S., Lee H.G., Microencapsulation of a-tocopherol using sodium alginate and its controlled release properties, International journal of biological macromolecules, 38(1), 2006, 25-30.

[22] Lertsutthiwong P., Noomun K., Jongaroonngamsang N., Rojsitthisak P., Nimmannit U., Preparation of alginate nanocapsules containing turmeric oil, Carbohydrate Polymers, 74(2), 2008, 209-214.

[23] Zhu G.Y., Xiao Z.B., Zhou R.J., Yi F.P., Fragrance and flavor microencapsulation technology, In Advanced Materials Research, Vol. 535, 2012, 440-445. Trans Tech Publications.

[24] Craigie J.S., Cell walls. In biology of the red algae, K.M. Cole and R.G., Cambrige University Press, 1990, 221-257.

[25] Murano E., Use of natural polysaccharides in the microencapsulation techniques, Journal of Applied Ichthyology, 14(3-4), 1998, 245-249. 
[26] Rochas C., Rinaudo M., Mechanism of gel formation in $\kappa$-carrageenan, Biopolymers, 23(4), 1984, 735-745.

[27] Dima C., Cotârlet M., Alexe P., Dima S., Microencapsulation of essential oil of pimento [Pimenta dioica (L) Merr.] by chitosan/k-carrageenan complex coacervation method, Innovative Food Science \& Emerging Technologies, 22, 2014, 203-211.

[28] Anal A.K., Singh H., Recent advances in microencapsulation of probiotics for industrial applications and targeted delivery, Trends in Food Science \& Technology, 18(5), 2007, 240-251.

[29] Shi L.E., Li Z.H., Zhang Z.L., Zhang T.T., Yu W.M., Zhou M.L., Tang Z.X., Encapsulation of Lactobacillus bulgaricus in carrageenan-locust bean gum coated milk microspheres with double layer structure, LWT-Food Science and Technology, 54.1, 2013, 147-151.

[30] Peniche C., Argüelles-Monal W., Peniche H., Acosta N., Chitosan: an attractive biocompatible polymer for microencapsulation, Macromolecular Bioscience, 3(10), 2003, 511-520.

[31] Muzzarelli R.A.A., Muzzarelli C., Chitosan chemistry: relevance to the biomedical sciences, In Polysaccharides I, 2005, 151-209, Springer Berlin Heidelberg.

[32] Sugano M., Fujikawa T., Hiratsuji Y., Hasegawa Y., Hypocholesterolemic effects of chitosan in cholesterol-fed rats, Nutr. Rep. Int, 18, 1978, 531-537.

[33] Tokura S., Ueno K., Miyazaki S., Nishi N., Molecular weight dependent antimicrobial activity by chitosan, In New Macromolecular Architecture and Functions, 1996, 199207, Springer Berlin Heidelberg.

[34] Hirano S., Tokura S., Proceedings of the Second International Conference on Chitin/ Chitosan. Japanese Soc. Chitin, Tottori Japan 1982.

[35] Peniche H., Osorio A., Acosta N., De La Campa A., Peniche C., Preparation and characterization of superparamagnetic chitosan microspheres: Application as a support for the immobilization of tyrosinase, Journal of applied polymer science, 98(2), 2005, 651-657.

[36] Shibasaki K., Matsukubo T., Shugihara N., Tashiro E., Tanabe Y., Takaesu Y., Kokku Eisei Gakai Zasshi, 1988, 38.

[37] Şenel S., Kremer M.J., Kaş S., Wertz P.W., Hıncal A.A., Squier C.A., Enhancing effect of chitosan on peptide drug delivery across buccal mucosa, Biomaterials, 21(20), 2000, 2067-2071.

[38] Pajunen E., Grönqvist A., Ranta B., Immobilized yeast reactor application in continuous secondary fermentation in industrial scale operation, In Proceedings of the European Brewing Convention Congress, Lisbon 1991, 361-368.

[39] Lommi H., Immobilized yeast for maturation and alcohol-free beer, Brew. Dist. Int, 5, 1990, 22-23.

[40] Pilkington P.H., Margaritis A., Mensour N.A., Russell I., Fundamentals of immobilised yeast cells for continuous beer fermentation: a review, Journal of the Institute of Brewing, 104(1), 1998, 19-31.

[41] Hayes S.A., Power J., Ryder D.S., Physiology of immobilised cells and the application to brewing, Brew. Dig. 66 (11), 1991, 28-33. 
[42] Nedovic V.A., Obradovic B., Leskosek-Cukalovic I., Vunjak-Novakovic G., Immobilized yeast bioreactor systems for brewing-recent achievements, In Engineering and manufacturing for biotechnology, 2001, 277-292, Springer Netherlands.

[43] Nedović V.A., Obradović B., Leskošek-Čukalović I., Trifunović O., Pešić R., Bugarski B., Electrostatic generation of alginate microbeads loaded with brewing yeast, Process Biochemistry, 37(1), 2001, 17-22.

[44] Wyss A., Von Stockar U., Marison I.W., Production and characterization of liquid-core capsules made from cross-linked acrylamide copolymers for biotechnological applications, Biotechnology and bioengineering, 86(5), 2004, 563-572.

[45] Stark D., Münch T., Sonnleitner B., Marison I.W., Stockar U.V., Extractive Bioconversion of 2-Phenylethanol from 1-Phenylalanine by Saccharomycescerevisiae. Biotechnology Progress, 18(3), 2002, 514-523.

[46] Ouwehand A.C., Salminen S.J., The health effects of cultured milk products with viable and non-viable bacteria, International Dairy Journal, 8(9), 1998, 749-758.

[47] Chandramouli V., Kailasapathy K., Peiris P., Jones M., An improved method of microencapsulation and its evaluation to protect Lactobacillus spp. in simulated gastric conditions, Journal of microbiological methods, 56(1), 2004, 27-35.

[48] McSweeney P.L., Biochemistry of cheese ripening. International Journal of Dairy Technology, 57(2-3), 2004, 127-144.

[49] Kailasapathy K., Lam S.H., Application of encapsulated enzymes to accelerate cheese ripening. International Dairy Journal, 15(6), 2005, 929-939.

[50] Anjani K., Kailasapathy K., Phillips M., Microencapsulation of enzymes for potential application in acceleration of cheese ripening, International Dairy Journal, 17(1), 2007, $79-86$.

[51] Wang W., Waterhouse G.I., Sun-Waterhouse D., Co-extrusion encapsulation of canola oil with alginate: effect of quercetin addition to oil core and pectin addition to alginate shell on oil stability, Food research international, 54(1), 2013, 837-851.

[52] Sun-Waterhouse D., Penin-Peyta L., Wadhwa S.S., Waterhouse G.I., Storage stability of phenolic-fortified avocado oil encapsulated using different polymer formulations and co-extrusion technology, Food and Bioprocess Technology, 5(8), 2012, 3090-3102.

[53] Choe E., Effects and mechanisms of minor compounds in oil on lipid oxidation, Food lipids: chemistry, nutrition, and biotechnology, 2008, 449-474.

[54] Neethirajan S., Jayas D.S., Nanotechnology for the food and bioprocessing industries. Food and bioprocess technology, 4(1), 2011,39-47. 